\title{
Fordulat az amerikai külpolitikában? - várakozások és realitások
}

Bár sokan egyfajta mérföldkőként tekintenek Joe Biden elnökválasztási győzelmére, az Amerikai Egyesült Államok 46. elnökétől nem várható stratégiai jellegü vagy mélységü fordulat végrehajtása az amerikai kül- és biztonságpolitikában. Alapvetően két ok miatt nem. Egyrészt Donald Trump négyéves elnöki ciklusa alatt nem az Egyesült Államok stratégiai helyzete vagy érdekei változtak meg. Trump és adminisztrációja ugyanis elsősorban megközelítésében és módszereiben változtatott az amerikai kül- és biztonságpolitika gyakorlatán. Másrészt azért sem várható stratégiai fordulat, mert Joe Bidennek is egy olyan poszthegemoniális világrendben kell az amerikai érdekeket képviselnie és érvényesítenie, amelyben az Egyesült Államok kül- és biztonságpolitikáját a legalapvetőbb módon - még ha nem is mindig látványosan, de - továbbra is a felemelkedő Kínával való konfliktusok uralják majd. Mindez természetesen nem jelenti azt, hogy az új adminisztráció ne törekedne, és ne törekedhetne a trumpi kül- és biztonságpolitikai örökség számos alapvető vagy lényeges elemének megváltoztatására.

Amennyiben a bideni kül- és biztonságpolitika várható új elemeit kell általánosságban számba vennünk, annyi bizonyosnak látszik, hogy ez a politika nem a trumpi külpolitika teljes visszájára fordítását jelenti majd, de nem is egyfajta visszatérést az Obamaadminisztráció külpolitikájához (amelynek Biden alelnökként az egyik fontos és alakító szereplője volt). Sokkal inkább az új adminisztráció szakítását a komoly kritikákat kiváltó trumpi tranzakcionalista külpolitikai gyakorlattal, fokozottabb globális felelősségvállalását az Egyesült Államok számára is fontos területeken, illetve a multilateralizmushoz és a klasszikus diplomáciához való visszatérését ott, ahol azt az amerikai érdekek feltétlenül megkövetelik. Ezek kapcsán Washingtonnak a WHO-hoz és a párizsi klímaegyezményhez való ismételt csatlakozását említhetjük példaként, illetve a szakértőknek azt a várakozását, hogy az új adminisztráció határozottabb politikát folytat majd a WTO-reformokkal kapcsolatban. A Trump-érához képest változást indukál majd az amerikai kül- és biztonságpolitikai gyakorlatban Joe Biden visszatérése az értékalapú külpolitikához, ami az új adminisztráció nyelvezetében, szóhasználatában és kommunikációjában már most is egyértelmüen érzékelhető. A változások dinamikáját ugyanakkor erősen befolyásol(hat) ják az amerikai belpolitika kihívásai, különösen a Covid-19-járvány gazdasági és politikai következményei.

Fontosabb azonban látnunk azt, hogy a poszthegemoniális helyzet alapvetően alakította és alakítja át az Egyesült Államok kül- és biztonságpolitikai magatartását, változtatja meg tartósan amerikai szempontból a világpolitika szereplőinek és eseményeinek helyiértékét.

Tálas Péter a Nemzeti Közszolgálati Egyetem Eötvös József Kutatóközpont Stratégiai Védelmi Kutatóintézet igazgatója. E-mail: talas.peter@uni-nke.hu 
Továbbá azt is, hogy a washingtoni kül- és biztonságpolitikára az Egyesült Államok stratégiai érdekeinek és nagystratégiájának lesz alapvető és döntő befolyása Joe Biden elnöksége alatt is, s nem - miként azt sokan remélik - az elnök személyiségének, az új adminisztráció politikai stílusának, módszereinek és eszközeinek, még kevésbé pedig az előzetes szövetségesi elvárásoknak. A nagystratégia első számú célja pedig Kína feltartóztatása marad Biden alatt is. 